\title{
Induction of DNA Breakage in U937 Cells by Oxazaphosphorines*
}

\author{
Lidia MAZUR, Małgorzata OPYDO-CHANEK, Marta STOJAK, Jarosław BARAN, and Ulf NIEMEYER
}

Accepted September 15, 2009

\begin{abstract}
MAZUR L., Opydo-ChaneK M., StojaK M., BARAn J., Niemeyer U. 2010. Induction of DNA breakage in U937 cells by oxazaphosphorines. Folia biol. (Kraków) 58: 15-20.

Oxazaphosphorines are a class of DNA alkylating agents. The aim of the present study was to compare the possible influence of three new generation oxazaphosphorines, D-17272 (mafosfamide cyclohexylamine salt), D-18864 (4-hydro-peroxy-cyclophosphamide), and D-19575 (glufosfamide, $\beta$-D-glucose-isophosphoramide mustard) on DNA damage induction in the human histiocytic lymphoma U937 cells. The flow cytometry APO-BRDU ${ }^{\mathrm{TM}}$ assay, based on the TUNEL method, was used for the in situ detection of DNA strand breaks. After exposure of U937 cells to the oxazaphosphorines, the patterns of temporary changes in the frequency of TUNEL positive U937 cells, expressing DNA breakage, were determined. The effects of the oxazaphosphorines on U937 cells were dependent on the agent tested and its dose, and the time intervals after the drug application. The different potential of D-17272, D-18864 and D-19575 to induce DNA strand breakage in the human histiocytic lymphoma
\end{abstract} U937 cells was shown.

Key words: Oxazaphosphorines, U937 cells, DNA strand breaks, TUNEL technique.

Lidia MAZUR, Matgorzata OPYDO-CHANEK, Marta STOJAK, Department of Experimental Hematology, Jagiellonian University, R. Ingardena 6, 30-060 Kraków, Poland.

E-mail: lidia.mazur@uj.edu.pl malgorzata.opydo-chanek@uj.edu.pl marta.stojak@uj.edu.pl

Jarosław BARAN, Department of Clinical Immunology, Polish-American Institute of Pediatrics, Jagiellonian University Medical College, Wielicka 265, 30-663 Kraków, Poland. E-mail:mibaran@cyf-kr.edu.pl

Ulf NIEMEYER, NIOMECH part of IIT GmbH, University of Bielefeld, Universitätsstr. 25,

33615 Bielefeld, Germany.

E-mail:ulf_niemeyer@t-online.de

Oxazaphosphorines belong to a class of anticancer alkylating agents. The oxazaphosphorines are very useful and effective in the treatment of a wide variety of hematological and non-hematological malignancies. These therapeutic drugs include the commonly used cyclophosphamide and ifosfamide (BROCK 1989; ADIS INTERNATIONAL LIMITED 2005; ZHANG et al. 2005a, 2005b). Recently, additional oxazaphosphorine derivatives, such as mafosfamide cyclohexylamine salt, 4-hydroperoxy-cyclophosphamide and glufosfamide, have been synthesized and tested for the improved activity against different types of cancer cells (ENGEL et al. 2000; SEKER et al. 2000; ZHANG et al. 2005a; MISIURA 2006; LIANG et al. 2007). These novel oxazaphosphorines, and especially glufosfamide, have attracted much attention in a broad spectrum of cancer therapy. The modes of their action are still under experimental and clinical investigations (BRIASOULIS et al. 2000, 2003; BRÖKER \& GIACCONE 2002; STYCZYŃSKI et al. 2002a, 2002b; VAN DEN BENT et al. 2003; DOLLNER et al. 2004; GIACCONE et al. 2004; ZHANG et al. 2005a, 2005b; AMMONS et al. 2007; CHIOREAN et al. 2008; GOLDSTEIN et al. 2008; MAZUR et al. 2008a, 2008b; CIULEANU et al. 2009).

There is a general consensus that DNA is the main target for a large number of anticancer drugs. The oxazaphosphorines are accepted to be DNA damaging agents. A better understanding of the action of these alkylating agents on DNA molecules of cancer cells is important for their optional use in chemotherapy (SEKER et al. 2000; BECKER et al. 2002). 
The aim of the present study was to compare the potential of three new generation oxazaphosphorines to induce DNA breakage in the human histiocytic lymphoma U937 cells. The in situ induction of DNA strand breaks in U937 cells subjected to the exposure to mafosfamide cyclohexylamine salt, 4-hydro-peroxy-cyclophosphamide and glufosfamide, was analyzed using the TUNEL method.

\section{Material and Methods}

\section{Cells}

Human histiocytic lymphoma U937 cells (American Type Culture Collection, Rockville, MD, USA) were maintained in RPMI 1640 (Gibco BRL Life Technologies) supplemented with $10 \%$ fetal calf serum (GIBCO BRL Life Technologies), $2 \mathrm{mM}$ L-glutamine (Sigma Aldrich), and antibiotic antimycotic solution (Sigma Aldrich) containing 20 units of penicillin, $20 \mu \mathrm{g}$ streptomycin and 0.05 $\mu \mathrm{g}$ amphotericin B. U937 cells were passaged every third day, by diluting to a concentration of $5 \times 10^{5}$ cells $/ \mathrm{ml}$ medium, and the cells grew exponentially at $37^{\circ} \mathrm{C}$ in an atmosphere of $5 \% \mathrm{CO}_{2}$ in air (HERAcell incubator, KendroLab). The cultures were periodically tested for Mycoplasma infection.

\section{Chemicals}

Mafosfamide cyclohexylamine salt (D-17272, CAS No. 84210-80-0), 4-hydro-peroxy-cyclophosphamide (D-18864, CAS No. 39800-16-3) and glufosfamide (D-19575, $\beta$-D-glucose-isophosphoramide mustard, CAS No. 132682-98-5) were obtained from NIOMECH (Bielefeld, Germany). D-17272, D-18864 and D-19575 were dissolved in aqua pro injectione (Polpharma, Poland). All solutions were freshly prepared directly before treatment of U937 cells.

\section{Drug doses and cell treatment}

After a dilution of the cell suspension to a density of $15 \times 10^{4}$ cells $/ \mathrm{ml}$, U937 cells were_subjected to 30 min exposure to the oxazaphosphorine drug. D-18864 was given at a dose of $5 \mu \mathrm{g} / \mathrm{ml}$ medium, D-19575 at a dose of $50 \mu \mathrm{g} / \mathrm{ml} \mathrm{medium,} \mathrm{and}$ D-17272 was applied at doses $5 \mu \mathrm{g} / \mathrm{ml}$ and $50 \mathrm{~g} / \mathrm{ml}$ medium. The control material consisted of untreated cells. After $30 \mathrm{~min}$ treatment with the oxazaphosphorine agent, U937 cells were centrifuged for $10 \mathrm{~min}$ at $1000 \mathrm{rpm}$ and the supernatant was discarded. Then the cells were washed in $2 \mathrm{ml}$ of PBS (BioMed) and pelletted by centrifugation for $7 \mathrm{~min}$. The wash and centrifugation were repeated once more and the cells resuspended in $5 \mathrm{ml}$ of the complete RPMI 1640 medium.

\section{Preparation procedure and fixation of cells}

Samples of the cell suspension were taken at $24 \mathrm{~h}, 48 \mathrm{~h}$ and $72 \mathrm{~h}$ after drug application. After 10 min centrifugation at $1000 \mathrm{rpm}$, and discarding the supernatant, the cells were washed twice in $2 \mathrm{ml}$ of PBS and pelletted by centrifugation for $7 \mathrm{~min}$. U937 cells were flushed out with PBS and dispersed by gentle pipetting. Finally, the cells were suspended in $500 \mu \mathrm{l}$ of PBS. After adding $5 \mathrm{ml}$ of $1 \%(\mathrm{w} / \mathrm{v})$ formaldehyde (Lach-Ner) in PBS, the cell suspension was placed on ice for $15 \mathrm{~min}$. Then, U937 cells were centrifuged for $7 \mathrm{~min}$ at $1000 \mathrm{rpm}$ and the supernatant was discarded. The cells were washed in $2 \mathrm{ml}$ of PBS and pelletted by centrifugation. The wash and centrifugation were repeated once more. The cells were resuspended in $500 \mu \mathrm{l}$ of PBS, and after adding $5 \mathrm{ml}$ of ice-cold $70 \%$ (v/v) ethanol, stored at $-20^{\circ} \mathrm{C}$ until use.

\section{APO-BRDU ${ }^{\mathrm{TM}}$ assay}

The APO-BRDU ${ }^{\mathrm{TM}}$ Kit (Calbiochem), a two color staining method for labeling DNA breaks and total cellular DNA was used. The 3' $\mathrm{OH}$ termini in the strand breaks can be analyzed by attaching FITC (fluorescein isothiocyanate)-labeled 5-bromo-2'-deoxyuridine 5'-triphosphate nucleotides (Br-dUTP), in a reaction catalyzed by exogenous terminal deoxynucleotidyl transferase (TdT). This reaction is known as TUNEL from TdTmediated dUTP nick-end labeling. The incorporation of Br-dUTP into DNA strand breaks, detected by FITC-conjugated anti-BrdU antibody, is combined with staining of DNA with propidium iodide (PI) (DARŻYNKIEWICZ et al. 2001). The kit consisted of washing, reaction, and rinsing buffers for processing individual steps in the assay, TdT, BrdUTP, fluorescein labeled anti-BrdU antibody for labeling DNA breaks and PI/RNase A solution for counter staining the total DNA.

\section{APO-BRDU ${ }^{\mathrm{TM}}$ protocol}

The leukemic cell suspension was centrifuged for $10 \mathrm{~min}$ at $1000 \mathrm{rpm}$ and the $70 \%$ ethanol was removed by aspiration. The cell pellet was resuspended with $1 \mathrm{ml}$ of wash buffer, centrifuged for $7 \mathrm{~min}$ at $1000 \mathrm{rpm}$ and the supernatant removed. The wash buffer treatment was repeated and the cell pellet resuspended in $50 \mu \mathrm{l}$ of the DNA labeling solution containing $10 \mu \mathrm{l}$ of TdT reaction buffer, $0.75 \mu \mathrm{l}$ of TdT enzyme, $8 \mu \mathrm{l}$ of Br-dUTP, 
and $32.25 \mu \mathrm{l}$ of distilled $\mathrm{H}_{2} \mathrm{O}$. The cells were incubated in the DNA labeling solution for $60 \mathrm{~min}$ at $37^{\circ} \mathrm{C}$ in a temperature controlled bath. At the end of incubation time, $1 \mathrm{ml}$ of rinse buffer was added to each tube, the cells centrifuged for $7 \mathrm{~min}$ at 1000 $\mathrm{rpm}$ and the supernatant removed by aspiration. Cell rinsing with $1 \mathrm{ml}$ of the rinse buffer was repeated, and then the cell pellet was resuspended in $100 \mu \mathrm{l}$ of the antibody solution containing $5 \mu \mathrm{l}$ of fluorescein labeled anti-BrdU antibody suspended in $95 \mu$ of the rinse buffer. The cells were incubated with the fluoresceinated antibody solution in the dark for $30 \mathrm{~min}$ at room temperature. Then, 300 $\mu \mathrm{l}$ of the propidium iodide/RNase A solution was added to the tube containing $100 \mu \mathrm{l}$ of the antibody solution, and the cells were incubated in the dark for $30 \mathrm{~min}$ at room temperature.

Flow cytometry analysis of leukemic cells

The fluorescence of individual U937 cells was measured by a flow cytometer (FACS Calibur,
Beckton Dickinson). Green fluorescence of FITC-conjugated anti-BrdU antibody was measured at $530-\mathrm{nm}$ and red fluorescence of propidium iodide at $>600 \mathrm{~nm}$. At least 5000 cells were analyzed per one sample.

\section{Results}

The effects of three oxazaphosphorines, D-17272, D-18864, and D-19575, on DNA degradation in U937 cells, were compared. Using the flow cytometry APO-BRDU ${ }^{\mathrm{TM}}$ assay, based on the in situ detection of DNA strand breaks, temporary changes in the frequency of TUNEL positive U937 cells were determined at 24h, 48h, and $72 \mathrm{~h}$ after the application of the oxazaphosphorine agent (Table 1, Fig. 1).

The frequency of DNA strand breaks was found to be smaller in U937 cells treated with D-17272, at a dose of $5 \mu \mathrm{g} / \mathrm{ml}$ medium, than in the cells exposed to D-18864, at the same dose. The frequency

Table 1

Effects of the oxazaphosphorines on DNA strand breaks - induction in U937 cells

\begin{tabular}{|c|c|c|c|c|}
\hline \multicolumn{2}{|c|}{$\begin{array}{l}\text { Time intervals } \\
\text { after cell exposure } \\
\text { to oxazaphosphorines }\end{array}$} & $24 \mathrm{~h}$ & $48 \mathrm{~h}$ & $72 \mathrm{~h}$ \\
\hline \multicolumn{2}{|c|}{ Experimental groups } & \multicolumn{3}{|c|}{ Frequency of U937 cells expressing DNA strand breaks } \\
\hline & drug given drug dose & Mean $\pm \mathrm{SD}$ & Mean \pm SD & Mean \pm SD \\
\hline I & D-18864 $5 \mu \mathrm{g} / \mathrm{ml}$ & $\begin{array}{c}2,3,4,5,72 \mathrm{~h} \\
38.27 \pm 1.12\end{array}$ & $\begin{array}{c}2,3,4,5 \\
42.67 \pm 5.41\end{array}$ & $\begin{array}{c}2,3,4,5,24 \mathrm{~h} \\
47.59 \pm 6.91\end{array}$ \\
\hline II & $5 \mu \mathrm{g} / \mathrm{ml}$ & $\begin{array}{c}1,5,48 \mathrm{~h}, 72 \mathrm{~h} \\
7.91 \pm 1.91\end{array}$ & $\begin{array}{l}1,3,5,24 \mathrm{~h} \\
5.41 \pm 0.42\end{array}$ & $\begin{array}{c}1,3,4,5,24 \mathrm{~h} \\
\quad 5.01 \pm 0.80\end{array}$ \\
\hline III & D-17272 $50 \mu \mathrm{g} / \mathrm{ml}$ & $\begin{array}{l}1,5,48 \mathrm{~h}, 72 \mathrm{~h} \\
11.49 \pm 1.95\end{array}$ & $\begin{array}{c}1,2,4,5,24 \mathrm{~h}, 72 \mathrm{~h} \\
63.83 \pm 4.61\end{array}$ & $\begin{array}{c}1,2,4,5,24 \mathrm{~h}, 48 \mathrm{~h} \\
76.02 \pm 2.71\end{array}$ \\
\hline IV & D-19575 $50 \mu \mathrm{g} / \mathrm{ml}$ & $\begin{array}{c}1,5 \\
9.11 \pm 2.56\end{array}$ & $\begin{array}{l}1,3,5,72 \mathrm{~h} \\
6.76 \pm 1.42\end{array}$ & $\begin{array}{l}1,2,3,5,48 \mathrm{~h} \\
11.79 \pm 1.70\end{array}$ \\
\hline V & control & $\begin{array}{c}1,2,3,4 \\
2.23 \pm 0.16\end{array}$ & $\begin{array}{c}1,2,3,4 \\
2.48 \pm 0.21\end{array}$ & $\begin{array}{c}1,2,3,4 \\
2.29 \pm 0.39\end{array}$ \\
\hline
\end{tabular}

Statistically significant differences at $\mathrm{P}<0.05$

Differences between groups: different from Group I - 1, Group II - 2; Group III - 3; Group IV - 4; Group V - 5.

Differences within each group: different from $24 \mathrm{~h}-24 \mathrm{~h} ; 48 \mathrm{~h}-48 \mathrm{~h} ; 72 \mathrm{~h}-72 \mathrm{~h}$. 

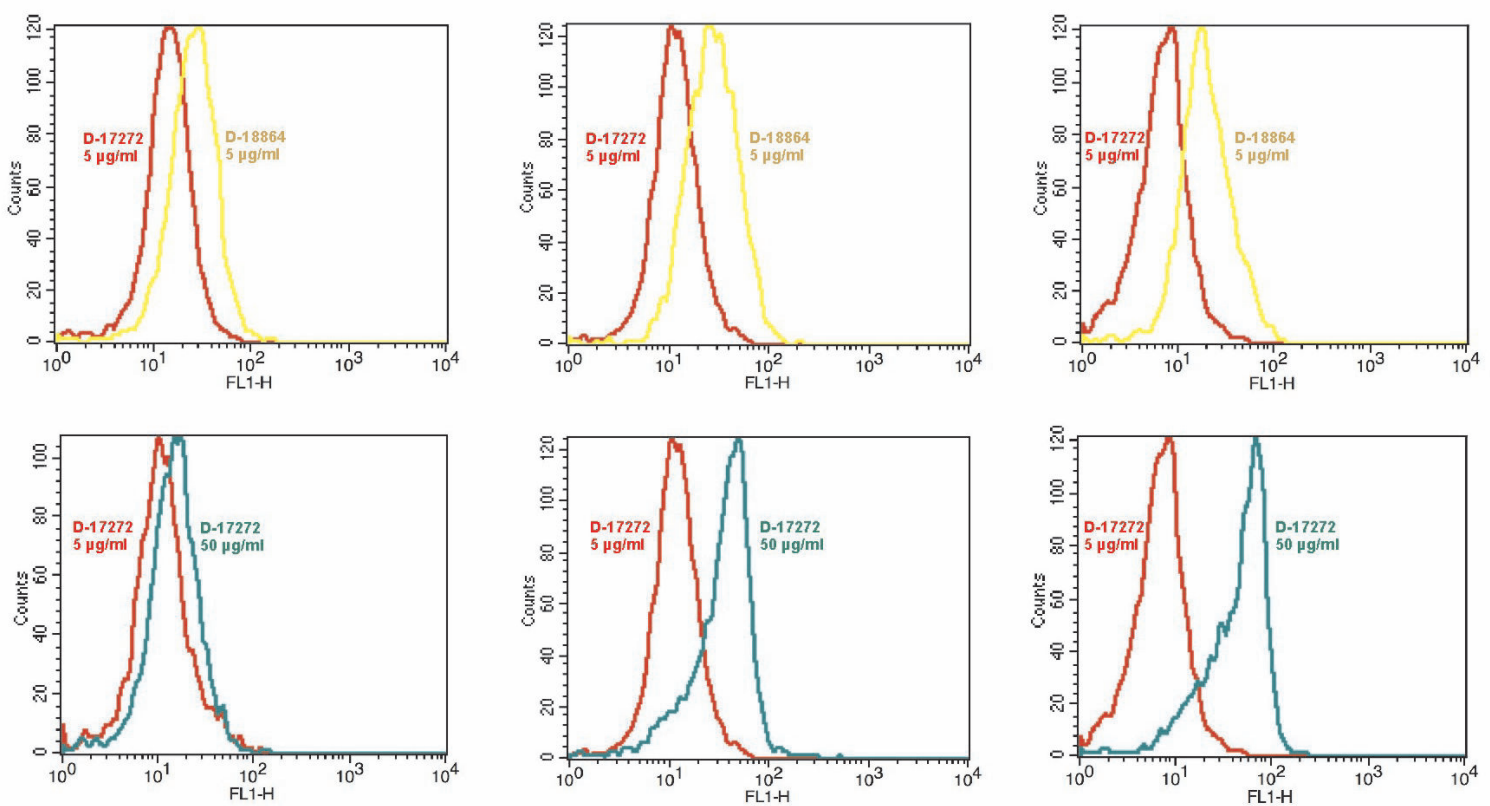

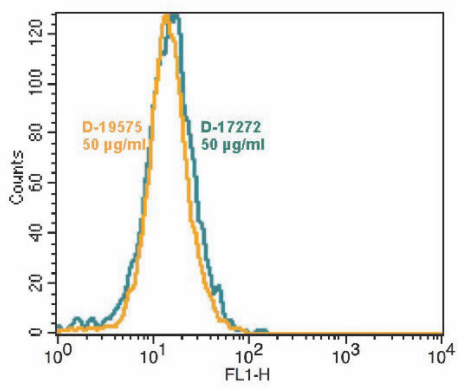

$24 \mathrm{~h}$

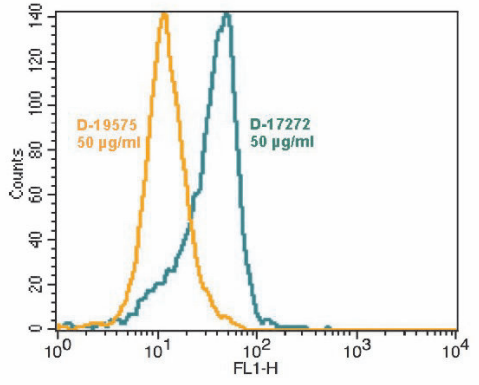

$48 \mathrm{~h}$

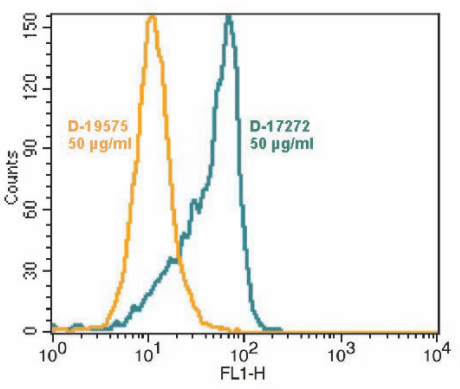

$72 \mathrm{~h}$

Fig. 1. In situ detection of DNA strand breaks in U937 cells after application of D-17272, D-18864 and D-19575, using flow cytometry APO-BRDU ${ }^{\mathrm{TM}}$ assay. Histograms of FITC green fluorescence intensities of U937 cells treated with: D-18864 $(5 \mu \mathrm{g} / \mathrm{ml}$ medium) - yellow line; D-17272 (5 $\mu \mathrm{g} / \mathrm{ml}$ medium) - red line; D-17272 (50 $\mu \mathrm{g} / \mathrm{ml}$ medium) - green line; D-19575 $(50 \mathrm{\mu g} / \mathrm{ml}$ medium) - orange line. FL1-H - BrdUTP-FITC.

of TUNEL positive cells, assessed at $48 \mathrm{~h}$ and $72 \mathrm{~h}$ after the exposure of U937 cells to D-17272, appeared to be respectively greater when the oxazaphosphorine agent was applied at the higher dose of $50 \mu \mathrm{g} / \mathrm{ml}$ than at the lower one of $5 \mu \mathrm{g} / \mathrm{ml}$ medium. The frequency of DNA strand breaks observed at $48 \mathrm{~h}$ and $72 \mathrm{~h}$ after D-19575 application, at a dose of $50 \mu \mathrm{g} / \mathrm{ml}$ medium, was respectively smaller as compared with that found after the treatment of U937 cells with D-17272, at the same dose. In comparison with the controls, the frequency of U937 cells expressing DNA strand breaks increased in all remaining experimental groups at all time intervals after the oxazaphosphorine application.

\section{Discussion}

The results of the present study have shown the influence of three new generation oxazaphos- phorines, D-17272, D-18864 and D-19575, on DNA breakage induction in the human histiocytic lymphoma U937 cells. The different patterns of temporary changes in the frequency of U937 cells expressing DNA strand breaks, were found at 24, 48 and $72 \mathrm{~h}$ after the alkylating drug application. DNA degradation was dependent on the compound tested and its dose, and the time intervals after the exposure of U937 cells to the oxazaphosphorine agent.

The mechanisms of action of D-17272, D-18864 and D-19575, have not yet been completely explained (BODY \& YULE 2000; ZHANG et al. 2005a). However, it is known that D-17272, mafosfamide cyclohexylamine salt, generates its active principle 4-hydroxy-cyclophosphamide (4-OH-CP) which degrades to phosphoramide mustard and acrolein. D-18864, that is 4-hydro-peroxy-cyclophosphamide, generates 4-OH-CP. Thus, phosphoramide mustard and acrolein are the major ultimate alkylating agents of the pro-drugs, D-17272 and D-18864 
(BODY \& YUlE 2000; KeHRER \& BisWAL 2000; ZHANG et al. 2005a, 2005b). Unlike these prodrugs, D-19575, $\beta$-D-glucose-isophosphoramide mustard, contains the directly active alkylating moiety, isophosphoramide mustard (IPM) linked to a $\beta$-D-glucose-molecule. Inside the cell, D-19575 hydrolyzes to IPM and $\beta$-D-beta-D-glucose (POHL et al. 1995; VEYHL et al. 1998; ENGEL et al. 2000; LIANG et al. 2007).

The cytotoxic effects of the oxazaphosphorines are thought to be dependent mainly on DNA alkylating properties. The active alkylating agents can bind to a variety of molecules, but the most important site of their binding is DNA. These active compounds can react with phosphate, amino, and hydroxyl groups of the bases of nucleic acids. The ultimate alkylating mustards from the oxazaphosphorines are the predominant metabolites that cause DNA damage such as adducts and crosslinks, and DNA strand breaks (SEKER et al. 2000; BECKER et al. 2002; ZHANG et al. 2005b). It is known that DNA damage can trigger programmed cell death. However, the mechanisms responsible for the activation of cellular death pathways leading to programmed cell death, due to the adduct and crosslink formation, and DNA breakage induction, have yet to be fully elucidated (GUIMARAES \& LINDEN 2004; ZHANG et al. 2005a, 2005b; GOLDSTEIN et al. 2008).

The modes of action of D-17272, D-18864 and D-19575 are suggested to be closely related to the pharmacokinetic, pharmacodynamic, and cytotoxic properties of these three oxazaphosphorine agents. It is believed that the oxazaphosphorine metabolism and transport have a major impact on pharmacokinetic variability, the pharmacokinetic-pharmacodynamic relationship, and cytotoxicity (MOORE 1991; POHL et al. 1995; STUBEN et al. 1996; VEYHL et al. 1998; BODY \& YULE 2000; ENGEL et al. 2000; BRIASOULIS et al. 2003; GIACCONE et al. 2004; ZHANG et al. 2005a, 2005b).

To summarize, the oxazaphosphorines D-17272, D-18864 and D-19575 distinctly affect DNA breakage formation in the human histiocytic lymphoma U937 cells. The results of the present investigation are the first data comparing the potential of these three alkylating agents, mafosfamide cyclohexylamine salt, 4-hydro-peroxy-cyclophosphamide, and glufosfamide, to induce DNA strand breaks in the malignant hematopoietic cells. An elucidation of the mechanisms and processes responsible for the different extent of DNA damage occurring in various types of cancer cells, following their exposure to the oxazaphosphorine agents, can facilitate the development of new therapeutic strategies.

\section{Acknowledgements}

The authors are very grateful to Ms. Urszula KŁAPUT for her excellent technical assistance.

\section{References}

ADIS INTERNATIONAl LIMITED. 2005. Glufosfamide: Beta-D-GlcIPM, D-19575. Drug. R\&D 6: 49-52.

Ammons W. S., Wang J. W., Yang Z., Tidmarsh G. F., HOFFMAN R. M. 2007. A novel alkylating agent, glufosfamide, enhances the activity of gemcitabine in vitro and in vivo. Neoplasia 9: 625-633.

BECKER R., RitTER A., EICHHORN U., LiPS J., BERTRAM B., WIESSLER M., ZDZIENICKA M. Z., KAINA B. 2002. Induction of DNA breaks and apoptosis in crosslinkhypersensitive V79 cells by cytostatic drug beta-Dglucosyl-ifosfamide mustard. Br. J. Cancer 86: 130-135.

BODY A. V., YULE S. M. 2000. Metabolism and pharmacokinetics of oxazaphosphorines. Clin. Pharmakokinet. 38: 291-304.

BRiasoulis E., Judson I., Pavlidis N., Beale P., WANDERS J., GROOT Y., VEERMAN G., SCHUESSLER M., NieBCH G., Siamopoulos K., TZAMAKOU E., RAMMOU D., Wolf L., WALKer R., HANAUSKE A. 2000. Phase I trial a 6-hour infusion of glufosfamide, a new alkylating agent with potentially enhanced selectivity for tumors that overexpress transmembrane glucose transporters: A study of the European Organization for Research and Treatment of Cancer Early Clinical Studies Group. J. Clin. Oncol. 18: $3535-3544$

Briasoulis E., Pavlidis N., Terret C., Bauer J., Fiedler W., SChÖFFSKI P., RAOUL J. L., HESS D., SELVAIS R., LACOMBE D., BACHMANN P., FUMOLEAU P. 2003. Glufosfamide administered using a 1-hour infusion given as firstline treatment for advanced pancreatic cancer. A phase II trial of the EORTC-new drug development group. Eur. J. Cancer 39: 2334-2340.

BROCK N. 1989. Oxazaphosphorine cytostatics: Pastpresent-future - Seventh Cain Memorial Award Lecture. Cancer Res. 49: 1-7.

BRÖKER L. E., GIACCONE G. 2002. The role of new agents in the treatment of non-small cell lung cancer. Eur. J. Cancer 38: 2347-2361.

Ciuleanu T. E., Pavlovsky A. V., Bodoky G., Garin A. M., LANGMUIR V. K., KROLL S. 2009. A randomized Phase III trial of glufosfamide compared with the best supportive care in metastatic pancreatic adenocarcinoma previously treated with gemcitabine. Eur. J. Cancer 45: 1589-1596.

Chiorean E., Dragovich T., HaMm J., Langmuir V., Kroll S., Jung D., COLOWICK A., Tidmarsh G., LOEHRER P. 2008. A phase 1 dose-escalation trial of glufosfamide in combination with gemcitabine in solid tumors including pancreatic adenocarcinoma. Cancer Chemother. Pharmacol. 61: 1019-1026.

DARŻYNKIEWICZ Z., LI X., BEDNER E. 2001. Use of flow and laser-scanning cytometry in analysis of cell death. (In: Methods in Cell Biology, Schwartz L. M., Ashwell J. D. eds. Academic Press, San Diego CA) 66: 69-109.

Dollner R., Dietz A., Kopun M., Helbig M., WAllner F. GRANZOW C. 2004. Ex vivo responsiveness of head and neck squamous cell carcinoma to glufosfamide, a novel alkylating agent. Anticancer Res. 24: 2947-2951.

Engel J., Klenner T., Niemeyer U., Peter G., Pohl J., SCHÜßLER M., SCHUPKE H., VOSS A., WIESSLER M. 2000. Glufosfamide. Drug. Future 25: 791-794.

Giaccone G., Smit E. F., DE JONGE M., Dansin E., BRIASOUlis E., ARDIZZONI A., DOUILLARD J. Y., SPAETH D., LACOMBE D., BARON B., BACHMANN P., FUMOLEAU P. 2004. Glufosfamide administered by 1-hour infusion as a second-line treatment for advanced non-small cell lung cancer: a phase II trial of the EORTC- New Drug Development Group. Eur. J. Cancer 40: 667-672.

Goldstein M., Roos W. P., KaInA B. 2008. Apoptotic death induced by the cyclophosphamide analogue mafosfamide in human lymphoblastoid cells: Contribution of DNA replication, transcription inhibition and Chk/p53 signaling. Toxicol. Appl. Pharmacol. 229: 20-32. 
Guimaraes C. A., Linden R. 2004. Programmed cell deaths. Eur. J. Biochem. 271: 1638-1650.

KEHRER J. P., BISWAL S. S. 2000. The molecular effect of acrolein. Toxicol. Sci. 57: 6-15.

Liang J., Huang M., DuAn W., Yu X. Q., Zhou S. 2007. Design of new oxazaphosphorine anticancer drugs. Curr. Pharm. Design 13: 963-978.

MAZUR L., Opydo-ChaneK M., NieMEYeR U. 2008a. Frequency of micronuclei induced in the mouse erythropoietic system by new generetion oxazaphosphorines. Acta Biol. Cracov., Ser. Zool. 50: 5-10.

MAZUR L., OPYDO-CHANEK M., STOJAK M., ADAMUS M., NIEMEYER U. 2008b. Cell death - inducing potential of new generation oxazaphosphorines and antimetabolites. $16^{\text {th }}$ Euroconference on Apoptosis, September, 6-9, 2008, Bern, Switzerland, Poster No.107.

MisiURA K. 2006. Ifosfamide. Metabolic studies, new therapeutic approaches and new analogs. Mini-Rev. Med. Chem. 6: $395-400$

MOORE M. J. 1991. Clinical pharmacokinetics of cyclophosphamide. Clin. Pharmacokinet. 20: 194-208.

Pohl J., Bertram B., Hilgard P., Nowrousian M. R., STUBEN J., WIESSLER M. 1995. D-19575 - a sugar-linked isophosphoramide mustard derivative exploiting transmembrane glucose transport. Cancer Chemother. Pharmacol. J. 35: 364-370.

Seker H., Bertram B., Burkle A., Kaina B., Pohl J., KOEPSEL L. H., WIEßLER M. 2000. Mechanistic aspects of the cytotoxic activity of glufosfamide, a new tumor therapeutic agent. Br. J. Cancer 82: 629-634.

Stuben J., Port R., Bertram B., Bollow U., Hull W. E., SCHAPER M., POHL J., WIESSLER M. 1996. Pharmacokinetics and whole-body distribution of the new chemotherapeutic agent beta-D-glucosylisophosphoramide and its effects on the incorporation of [methyl-3H]-thymidine in various tissues of the rat. Cancer Chemother. Pharmacol. 38: 355-365.

STYCZYŃSKI J., WYSOCKI M., DEBSKI R., BALWIERZ W., ROKICKA-MILEWSKA R., MATYSIAK M., BALCERSKA A., KOWALCZYK J., WACHOWIAK J., SOŃTA-JAKIMCZYK D., CHYBICKA A. 2002a. In vitro activity of oxazaphosphorines in childhood acute leukemia: Preliminary report. Acta Biochim. Pol. 49: 221-225.

STYCZYŃSKI, WYSOCKI M., KUR YLAK A., JURASZEWSKA E., Malinowska I., StanczaK E., PŁoszyńsKa A. , STEFANIAK J., MAZUR B., SZCZEPAŃSKI T., RAS M. 2002b. In vitro activity of glufosfamide in childhood acute leukemia. Anticancer Res. 22: 247-250.

VAN DEN BENT M. J., GRISOLD W., FRAPPAZ D., STUPP R., DESIR J. P., LESIMPLE T., DITTRICH C., DE JONGE M. J. A., BRANDES A., Frenay M., CARPENTIER A. F., Chollet P., Oliveira J., Baron B., LacomBe D., SCHUESSLER M., FUMOLEAU P. 2003. European Organization for Research and Treatment of Cancer (EORTC) open label phase II study on glufosfamide administered as a 60-minute infusion every 3 weeks in recurrent glioblastoma multiforme. Ann. Oncol. 14: $1732-1734$.

VEYHL M., WAGNER K., VOLK C., GORBOUleV V., BAuMgarten K., Weber W. M., SChaper M., Bartram B., WeISSLER M., KoePSEll H. 1998. Transport of new chemotherapeutic agent beta-D-glucosylisophosphoramide mustard (D-19575) into tumor cells mediated by $\mathrm{Na}^{+}-\mathrm{D}-$ -glucose cotransporter SAAT1. Proc. Natl. Acad. Sci. USA 95: 2914-2919.

ZHANG J., Tian Q., Yung CHAN S., CHUEN Li S., ZHOU S., DUAN W., ZHU Y. Z. 2005a. Metabolism and transport of oxazaphosphorines and the clinical implications. Drug. Metab. Rev. 37: 611-703.

Zhang J., Tian Q., Yung Chan S., Duan W., Zhou S. 2005b. Insights into oxazaphosphorine resistance and possible approaches to its circumvention. Drug Resist. Update 8: 271-297. 